\section{EFFECT OF MEDICINAL PLANT Potentilla fulgens AGAINST FECUNDITY, HATCHABILITY AND SURVIVAL OF Fasciola HOST SNAIL Indoplanorbis exustus}

\author{
PRADEEP KUMAR ${ }^{1}$ \\ Department of Zoology, S.G.N. Govt. P.G. College, Muhammadabad Gohna, Mau, Uttar Pradesh, India
}

\begin{abstract}
Fascioliasis is one of the most widespread food-borne trematode infections. The snail is one of the most important intermediate hosts of the fascioliasis. The control of the snail population is one of the important methods in the campaign to reduce the incidence of fascioliasis among both cattle and human populations. To achieve this objective, the use of plantderived molluscicide is an appropriate approach to the control of the host snail populations. The present study was to observe the effects of sub- lethal $\left(20 \%\right.$ and $60 \%$ of $\left.24 \mathrm{~h} \mathrm{LC}_{50}\right)$ doses of Potentilla fulgens root powder, different organic extract and column purified fraction on the; fecundity, hatchability and survival of Fasciola vectors snail Indoplanorbis exustus. The plantderived molluscicides significantly reduced the reproductive capacity of the freshwater snail $I$. exustus. Maximum reduction in fecundity (32.53\% of control) was observed in snail treated with ethanol column purified fraction of the root powder of $P$. fulgens. In the withdrawal group significant recovery was observed in all treatments of the snails $(49.71 \%$ of control). The hatching period of an egg laid by the treated group was prolonged from 9 to 20 days concerning 9 to 10 days in control snails. The research study revealed that the active component of $\boldsymbol{P}$. fulgens can be used to make significant sterility in snails as well as in the development of embryonic stages.
\end{abstract}

KEYWORDS: Reproduction, Potentilla fulgens, Fecundity, Hatchability, Indoplanorbis exustus, Fascioliasis

Fascioliasis is a global zoonotic disease which caused by two species of flukes (Fasciola hepatica and $F$. gigantica), with complex life cycles involving freshwater snails as well as mammalian hosts, that mainly infected sheep, goat, and cattle, but can infect human after ingestion of metacercaria larva of flukes with contaminated water or aquatic vegetations (Mas-Coma et al, 2014, 2018). According to WHO 2.4 million, human populations are infected with Fasciola and a further 180 million are at risk of infection (Cwiklinski, 2016). The infestation of fascioliasis contributes to huge financial losses in the livestock industry and is associated with significant illness and morbidity, mainly in lower-income farming communities (Mas-Coma et al, 2018). The fresh water snail I. exustus is an intermediate host for the liver fluke $F$. gigantica in the Northern part of Uttar Pradesh (India), which caused endemic fascioliasis (Singh and Agarwal, 1981, Kumar et al., 2011, Kumar et al., 2012; Singh et al., 2012, Kumar et al., 2014, Kumar et al., 2018). Fascioliasis caused immense economic losses such as lower production of milk, wool and meat, reduces weight gain, and impaired fertility (Agarwal Singh, 1988, Parr and Gray, 2000, Kumar and Singh, 2006) of infected animals. One of the possible approaches to control of the fascioliasis infestations by the control of intermediate host snail population below the threshold level. Many chemically diverse plant molluscicide have been isolated and identified (Singh et al., 1996). However, the natural products in general, have an advantage over synthetic products, because natural products have biodegradable, eco-friendly and hence are less likely to accumulate in the environment. Previously, it has been reported by us that different organic root extract of Potentilla fulgens against liver fluke vector snail Indoplanorbis exustus was potent molluscicide (Kumar et al., 2018). In the present study focused on the plant-derived molluscicides containing sub-lethal $\left(20 \%\right.$ and $60 \%$ of $\left.24 \mathrm{~h} \quad \mathrm{LC}_{50}\right)$ doses of Potentilla fulgens root powder, different organic extract and column purified fraction on the, fecundity, hatchability and survival of the fascioliasis vectors snail Indoplanorbis exustus.

\section{MATERIALS AND METHODS}

\section{Study Area}

The study was carried out at Department of Zoology in quality control lab, S.G.N. Govt. P.G. College Muhammadabad Gohna Mau (U.P.) India from November, 2019 to December 2019.

\section{Experimental Animal}

Adult snail Indoplanorbis exustus $(0.85 \pm 0.20 \mathrm{~cm}$ in length) were collected from low lying submerged field 
of Gorakhpur (U.P.) India. The snails were allowed to acclimatize for 72 hours in dechlorinated tap water at 23 to $25^{\circ} \mathrm{C}$ in laboratory conditions. The $\mathrm{pH}$ of the water was 7.1-7.3 and dissolved oxygen, free carbon dioxide and bicarbonate alkalinity were $6.2-7.3 \mathrm{mg} / \mathrm{l}, 5.1-6.2 \mathrm{mg} / \mathrm{l}$ and $104.0-105.0 \mathrm{mg} / \mathrm{l}$, respectively.

\section{Preparation of Crude Products of the Plant}

The freshly dried root of Potentilla fulgens was procured from the local market in Gorakhpur, (UP) India. The dried root of $P$. fulgens was pulverized separately in the electric grinder and the crude powders thus obtained, were then sieved with the help of fine mesh cloth. This fine powder was then used separately for fecundity, hatchability and survival of the vector snail I. exustus.

\section{Extraction of Crude Products}

Two-gram dried roots powder of plant $P$. fulgens were extracted with $200 \mathrm{ml}$ of $98 \%$ ether, $99.7 \%$ chloroform, 98\% methanol, 98\% acetone, and 95\% ethanol at room temperature for $24 \mathrm{~h}$. Each preparation was subsequently filtered using Whatman qualitative filter papers (Whatman International Ltd, UK) and the filtered extracts where subsequently evaporated under vacuum (Kumar and Singh, 2006). The residues, thus obtained, were used for the determination of molluscicidal activity. The root powder of $P$. fulgens yielded $250 \mathrm{mg}$ ethanol, $350 \mathrm{mg}$ chloroform, $360 \mathrm{mg}$ ether, $415 \mathrm{mg}$ acetone extracts and chemicals purchased from Sigma Chemical Co.USA.

\section{Preparation of Column Purified}

One hundred milliliters of ethanol extract fraction of dried root powder of $P$. fulgens was subjected to silica gel (60-120 mesh, Qualigens Glass, Precious Electrochemidus Private Limited, Bombay, India) chromatography through a $5 \times 45 \mathrm{~cm}$ column. Fivemilliliter fractions eluted with ethanol $(95 \%)$ were collected. Ethanol was evaporated under vacuum and the remaining solids obtained were used for the fecundity, hatchability and survival of the vector snail each fraction.

\section{Sub-Lethal Treatment of Experimental Animal}

Snails were treated with sub-lethal $(20 \%$ and $60 \%$ of $24 \mathrm{~h} \mathrm{LC}_{50}$ ) concentration of dried root powder of $P$. fulgens, different organic extracts and column purified fractions on the reproduction was studied by the method of Kumar et al., (2013). Groups of 20 snails in 3L water were treated with sub-lethal concentrations $(20 \%$ and $60 \%$ of $24 \mathrm{~h} \mathrm{LC}_{50}$ ) root powder of $P$. fulgens, of different organic extracts and column purified fractions for the fecundity, hatchability and survival of the snails.

\section{Fecundity, Hatchability and Survivability of the Experimental Animal}

These experiments were performed according to the method of Kumar et al., (2013). The total number of eggs laid by sub-lethal ( $20 \%$ and $60 \%$ of $24 \mathrm{~h} \mathrm{LC}_{50}$ ) concentration of plant-derived molluscicides and control group of snails were counted after every $24 \mathrm{~h}$ for $96 \mathrm{~h}$. Since it is difficult to detect the mother snails for the particular spawn, capsules containing eggs from each treated and control group were incubated at $30^{\circ} \mathrm{C}$ in covered Petri dishes containing the same concentration as those given to adult snails. The development of embryos at regular intervals was observed under a binocular microscope until they hatched. A dead embryo lacks embryonic movements and becomes opaque. Dead embryos were removed to avoid any contamination. Young snails were immediately transferred to fresh-water and their survival was observed up to $72 \mathrm{~h}$ after hatching. Each experiment was replicated six times. In a withdrawal experiment, snail was transferred to fresh water after $96 \mathrm{~h}$ of exposure to the above-mentioned treatment and their fecundity was observed for the next $72 \mathrm{~h}$.

\section{Statistical Analysis}

Each experiment was replicated at least 6 times. Values were expressed as Mean \pm SE. Students t-test was applied to determine the significant $(\mathrm{P}<0.05)$ difference between sub-lethal treated and control group of the animals. The product moment correlation coefficient was applied in between exposure time and different values of fecundity/ survival of hatched snails (Sokal and Rohlf, 1973).

\section{RESULTS}

In control groups of 20 snails laid 210-225 eggs/day. There was a significant $(\mathrm{p}<0.05)$ reduction in the fecundity of snail I. exustus treated with a sub-lethal concentration of the 20 and $60 \%$ of $\mathrm{LC}_{50} / 24 \mathrm{~h}$ of dried root powder, ether extract, chloroform extract, methanol extract, acetone extract, ethanol extract and column purified fractions as a molluscicide (Table 1) No egg lying after $48 \mathrm{~h}$ was observed in snails treated with $60 \%$ of 24h $\mathrm{LC}_{50}$ of column purified fractions of dried root powder of Potentilla fulgens. The hatching period was prolonged in the treated group (9-20 days) to control group (9-10 days) (Table 2). Withdrawal of snail after 96h treated snail for the next $72 \mathrm{~h}$ in fresh water caused a significant $(\mathrm{P}<0.05)$ recovery in the fecundity of snails to their corresponding treatment (Table 1). 
After $48 \mathrm{~h}$ no survival of young snail was noted in treated with $60 \%$ of $24 \mathrm{~h} \mathrm{LC}_{50}$ of ethanol extract, whereas after $24 \mathrm{~h}$ no survival was observed in young snail treated with $20 \%$ or $60 \%$ of $24 \mathrm{~h} \mathrm{LC}_{50}$ of column purified fractions (Table 2). There was a significant
$(\mathrm{P}<0.05)$ negative correlation between the treated time and survival of young snails hatched from eggs laid by snail treated to $20 \%, 60 \%$ of $24 \mathrm{~h} \mathrm{LC}_{50}$ of different organic fractions (Table 2).

Table 1: Effect of sub-lethal (20\% and $60 \%$ of $24 \mathrm{~h}$ LC 50 ) molluscicide of Potentilla fulgens (root powder, ether extract, chloroform extract, methanol extract, acetone extract, ethanol extract and column purified) on the fecundity of the snail Indoplanorbis exustus

\begin{tabular}{|c|c|c|c|c|c|}
\hline $\begin{array}{c}\text { Treatment (Sub- } \\
\text { lethal concentration } \\
\text { of }{ }^{\# 24 h} L_{C} C_{50} \text { of } 20 \\
\text { and } 60 \% \text { ) }\end{array}$ & $\begin{array}{c}\text { Fecundity } \\
\text { after } 24 \mathrm{~h} \\
\text { (eggs/20 snail) }\end{array}$ & $\begin{array}{c}\text { Fecundity } \\
\text { after } 48 \mathrm{~h} \\
\text { (eggs/20 snail) }\end{array}$ & $\begin{array}{c}\text { Fecundity } \\
\text { after } 72 \mathrm{~h} \\
(\text { eggs/20 snail) }\end{array}$ & $\begin{array}{c}\text { Fecundity } \\
\text { after } 96 \mathrm{~h} \\
\text { (eggs/20 snail) }\end{array}$ & $\begin{array}{l}\text { Withdrawal after } \\
\text { 96h treated snails } \\
\text { Fecundity after } 72 \mathrm{~h} \\
\text { (eggs/20 snails) }\end{array}$ \\
\hline Control & $185.43 \pm 0.13$ & $177.20 \pm 0.44$ & $170.16 \pm 0.41^{*}$ & $189.61 \pm 0.32^{*}$ & $192.30 \pm 0.43$ \\
\hline \multirow{2}{*}{ P. fulgens (DRP) } & ${ }^{+} 160.22 \pm 0.62^{*}$ & $158.63 \pm 0.45^{*}$ & $155.48 \pm 0.32^{*}$ & $146.25 \pm 0.12^{*}$ & $168.30 \pm 0.14$ \\
\hline & ${ }^{+} 158.28 \pm 0.32^{*}$ & $155.31 \pm 0.38^{*}$ & $150.09 \pm 0.72^{*}$ & $144.23 \pm 0.31^{*}$ & $162.34 \pm 0.16$ \\
\hline \multirow[t]{2}{*}{ Ether extract } & $+149.35 \pm 0.21^{*}$ & $147.15 \pm 0.82^{*}$ & $143.62 \pm 0.81^{*}$ & $140.59 \pm 0.70^{*}$ & $152.13 \pm 0.43$ \\
\hline & ${ }^{+} 146.62 \pm 0.60^{*}$ & $142.92 \pm 0.62^{*}$ & $138.22 \pm 0.56^{*}$ & $136.40 \pm 0.29^{*}$ & $149.41 \pm 0.22$ \\
\hline \multirow[t]{2}{*}{ Chloroform extract } & ${ }^{+} 137.30 \pm 0.72^{*}$ & $134.60 \pm 0.82^{*}$ & $133.54 \pm 0.21^{*}$ & $131.27 \pm 0.52^{*}$ & $140.38 \pm 0.52$ \\
\hline & ${ }^{+} 134.55 \pm 0.62^{*}$ & $132.79 \pm 0.10^{*}$ & $130.16 \pm 0.80^{*}$ & $129.32 \pm 0.13^{*}$ & $138.90 \pm 0.82$ \\
\hline \multirow[t]{2}{*}{ Methanol extract } & ${ }^{+} 135.83 \pm 0.43^{*}$ & $134.62 \pm 0.42^{*}$ & $130.50 \pm 0.43^{*}$ & $129.52 \pm 0.52^{*}$ & $138.62 \pm 0.43$ \\
\hline & $+131.69 \pm 0.12^{*}$ & $129.26 \pm 0.38^{*}$ & $127.42 \pm 0.42^{*}$ & $124.63 \pm 0.40^{*}$ & $134.83 \pm 0.20$ \\
\hline \multirow[t]{2}{*}{ Acetone extract } & ${ }^{+} 128.40 \pm 0.25^{*}$ & $125.60 \pm 0.12^{*}$ & $123.30 \pm 0.41^{*}$ & $120.60 \pm 0.58^{*}$ & $131.28 \pm 0.52$ \\
\hline & ${ }^{+} 125.23 \pm 0.20^{*}$ & $124.73 \pm 0.26^{*}$ & $121.60 \pm 0.43^{*}$ & $119.80 \pm 0.83^{*}$ & $127.66 \pm 0.80$ \\
\hline \multirow[t]{2}{*}{ Ethanol extract } & ${ }^{+} 98.41 \pm 0.42^{*}$ & $96.72 \pm 0.63^{*}$ & $85.29 \pm 0.33^{*}$ & $82.60 \pm 0.35^{*}$ & $103.99 \pm 0.82$ \\
\hline & $+66.43 \pm 0.59^{*}$ & $63.57 \pm 0.92^{*}$ & $60.12 \pm 0.62^{*}$ & $85.42 \pm 0.32^{*}$ & $71.60 \pm 0.30$ \\
\hline \multirow[t]{2}{*}{ Column purified } & $+47.52 \pm 0.32^{*}$ & - & - & - & $50.65 \pm 0.43$ \\
\hline & $+32.53 \pm 0.80^{*}$ & - & - & - & $49.71 \pm 0.11$ \\
\hline
\end{tabular}

\# Kumar et al., (2018). Each value is mean \pm SE of six replicates. Each replicates represents the egg laid by the group of 20 snails. $\left.{ }^{*}\right)$ significant $(\mathrm{P}<0.05)$ when student " $\mathrm{t}$ " test was applied to treated and control groups. $(+)$ product moment correlation coefficient showed that there was a significant $(\mathrm{P}<0.05)$ negative correlation between the exposure period and fecundity of snail I. exustus. (-) No fecundity was observed. Abbreviations: DRP- dried root powder.

Table 2: Effect of sub-lethal (20\% and $60 \%$ of $24 \mathrm{~h} \mathrm{LC50)}$ molluscicide of Potentilla fulgens (root powder, ether extract, chloroform extract, methanol extract, acetone extract, ethanol extract and column purified) on the hatchability and survival of the snail Indoplanorbis exustus eggs obtained after $24 \mathrm{~h}$ in table1.

\begin{tabular}{|c|c|c|c|c|}
\hline $\begin{array}{c}\text { Treatment (Sub-lethal } \\
\text { concentration of 24 h LC } \\
\mathbf{5 0}\end{array}$ & $\begin{array}{c}\text { Hatchability } \\
\text { 20 and 60\%) }\end{array}$ & $\begin{array}{c}\text { Percent survival } \\
\text { after 24h }\end{array}$ & $\begin{array}{c}\text { Percent survival } \\
\text { after 48h }\end{array}$ & $\begin{array}{c}\text { Percent survival } \\
\text { after 72h }\end{array}$ \\
\hline $\begin{array}{c}\text { pentrod) } \\
\text { P. fulgens (DRP) }\end{array}$ & $100(9-10)$ & 100 & 100 & 100 \\
& $149.18 \pm 0.32(9-14)$ & $147.40 \pm 0.30^{*}$ & $144.51 \pm 0.32^{*}$ & $141.60 \pm 0.62^{*}$ \\
Ether extract & $147.41 \pm 0.56(9-15)$ & $145.61 \pm 0.40^{*}$ & $143.60 \pm 0.82^{*}$ & $139.98 \pm 0.44^{*}$ \\
& $146.26 \pm 0.32(9-15)$ & $144.53 \pm 0.38^{*}$ & $140.16 \pm 0.85^{*}$ & $138.50 \pm 0.62^{*}$ \\
Chloroform extract & $143.62 \pm 0.60(9-16)$ & $140.32 \pm 0.66^{*}$ & $138.58 \pm 0.52^{*}$ & $136.63 \pm 0.11^{*}$ \\
& $141.80 \pm 0.22(9-14)$ & $139.70 \pm 0.53^{*}$ & $136.40 \pm 0.23^{*}$ & $134.80 \pm 0.32^{*}$ \\
Methanol extract & $139.42 \pm 0.53(9-15)$ & $137.65 \pm 0.62^{*}$ & $134.42 \pm 0.42^{*}$ & $132.60 \pm 0.62^{*}$ \\
& $138.30 \pm 0.52(9-15)$ & $136.35 \pm 0.31^{*}$ & $132.63 \pm 0.66^{*}$ & $130.61 \pm 0.22^{*}$ \\
Acetone extract & $134.60 \pm 0.66(9-17)$ & $133.60 \pm 0.55^{*}$ & $130.30 \pm 0.52^{*}$ & $128.62 \pm 0.24^{*}$ \\
Ethanol extract & $133.32 \pm 0.82(9-16)$ & $131.60 \pm 0.52^{*}$ & $128.50 \pm 0.53^{*}$ & $126.82 \pm 0.12^{*}$ \\
Column purified & $130.52 \pm 0.83(9-17)$ & $127.53 \pm 0.13^{*}$ & $125.60 \pm 0.81^{*}$ & $123.30 \pm 0.92^{*}$ \\
& $129.65 \pm 0.72(9-17)$ & $120.60 \pm 0.31^{*}$ & $105.50 \pm 0.72^{*}$ & $94.31 \pm 0.62^{*}$ \\
& $126.53 \pm 0.31(9-18)$ & $80.63 \pm 0.63^{*}$ & - & - \\
\end{tabular}

Each value is mean \pm SE of six replicates. Each replicates represent the egg laid by the group of 20 snails $(*)$ significant $(\mathrm{P}<0.05)$ when student " $t$ " test was applied to treated and control groups. (-) No fecundity was observed. Abbreviations: DRP- dried root powder. 


\section{DISCUSSION}

The result section indicates that sub-lethal molluscicidal concentration $\left(20 \%\right.$ and $60 \%$ of $24 \mathrm{~h} \mathrm{LC}_{50}$ of dried root powder, different organic extracts column purified fractions of Potentilla fulgens) significantly $(\mathrm{P}<0.05)$ reduced the reproductive capacity of snail $I$. exustus. Molluscicidal activity different organic extracts and column purified fractions of $60 \%$ of the $24 \mathrm{~h} \mathrm{LC}_{50}$ significantly $(\mathrm{P}<0.05)$ reduced the fecundity of I. exustus within $72 \mathrm{~h}$. Maximum reduction in the fecundity was observed in $60 \%$ sub-lethal concentration of $24 \mathrm{~h} \mathrm{LC}_{50}$ of column purified fractions $P$. fulgens. Several plant products have been effectively used for control of snail reproduction (Marston and Hostettmann, 1985, MelloSilva et al., 2007, Kumar et al., 2009). Kumar et al., (2009) have reported the plant-derived molluscicide (ferulic acid, umbelliferone, eugenol and limonene) influence on the fecundity of snail L. acuminata.

Hemalatha et al., (2013) have been reported the ethanolic root extract of $P$. fulgens preventing gastric ulcers in rats due to antihistaminic and $\mathrm{H}^{+} \mathrm{K}^{+}$-ATPase inhibitory activities. It may be possible that the different active components of $P$. fulgens in snail body could change the different enzyme activity. Roy et al., (2010) have been reported that the alcoholic extract of dried root powder of $P$. fulgens reduced significantly vital tegumental enzyme activity of acid phosphatase, alkaline phosphatase and adenosine triphosphatase (ATPase) in cestodes parasite Raillietina echinobothrida and trematodes Gastrothylax crumenifer, respectively. The acid phosphatase, a lysosomal enzyme (Aruna et al., 1979), plays an important role in catabolism pathological necrosis autolysis, and phagocytosis (Abou-Donia, 1978). The enzyme alkaline phosphatase plays a critical role in protein synthesis (Tripathi et al., 2004), shell formation (Timmermans, 1968), other secretary activities (Jaiswal et al., 2010), and transport of metabolites (Kumar et al., 2012) in gastropods. $P$. fulgens root extract is rich in polyphenolic components (Hemalatha et al., 2013) with the maximum quantity of phenolic tannins. Jaitak et al., (2010) have been reported the root extract of medicinal plant $P$. fulgens contain high amount of flavonoid and tannin components. Different plants families have a variety of tannins which are use as molluscicides (Ayoub and Yankow, 1986). It may be possible that different active components of $P$. fulgens diffuse in the host snail body and inhibit certain enzymes activities. It may affect the caudodarsal cells (CDSs) in the brain and ultimately decrease the release of the ovulation hormone that resulted a decrease in the fecundity of the snails. Singh and Singh (2004) have reported that the caudodarsal cell is responsible for the fecundity of freshwater host snail Lymnaea acuminata. Different experimental studies previously disclosed that root extract of $P$. fulgens have antitumor (Rosangkima and Prasad, 2004), antioxidant (Jaitak et al., 2010), gastroprotective (Hemalatha et al., 2013) and anthelmintic (Roy et al., 2010) properties.

The reduction in percent hatchability of eggs laid by $I$. exustus treated with sublethal concentrations of different organic extract and column purified fraction of $P$. fulgens as molluscicides with the embryonic development and growth of the snails. The snails, young larvae were weak, unable to break the egg capsule, and died owing to starvation. The young snails $I$. exustus hatched from the treated egg masses showed a delay in attaining maturity in comparison with the control groups. In general, the egg shells were thinner, and the hatchlings had shorter tentacles and slower movement and were smaller in size as compared with the control group. Mortality and low reproduction in treated snails suggest the active molluscicidal components in organic extract and column purified was able to reduce the fascioliasis vector snail population by inhibiting development at any stage of I. exustus growth.

Therefore, the transfer of mother snails to freshwater for the next $72 \mathrm{~h}$ after $96 \mathrm{~h}$ leads to a significant recovery in the fecundity. Thus, recovery of the effects would be an added advantage in their use against harmful snails. The plant-derived molluscicides/ molluscicidal components are easily available and biodegradable with sub-lethal molluscicides is a new concept for the control of harmful snail population below the threshold level.

\section{CONCLUSION}

In conclusion the present study suggests that the plant $P$. fulgens have anti-reproductive capacity against fresh-water snail $I$. exustus. The sub-lethal doses of column purified fractions of root powder of P. fulgens alter the reproductive capacity, inhibiting the development, growth of young ones and also possess a capability of making them sterile in the snail. Besides, it also causes death of embryo during development stages, kill the eggs thereby inhibiting hatching and its increases the mortality of the hatched snails.

\section{SIGNIFICANCE STATEMENT}

The present study revealed that the active component of $P$. fulgens can be used to make significant sterility in snails as well as in the development of embryonic stages, and it indicates the further studies that 
how their active components cause an impact on the molecular level in the snail body.

\section{REFERENCES}

Abou-Donia M.B., 1978. Increased acid phosphatase activity in hens following an oral dose of leptophos. Toxicol. Lett, 2: 199-203.

Agarwal R.A. and Singh D.K., 1988. Harmful gastropods and their control. Acta. Hydrochim. Hydrobiol, 16: 113-38.

Aruna P., Chetty C.S., Naidu R.C. and Swami K.S., 1979. Acid phosphatase activity in Indian apple snail, Pila globosa (Swainson), during aestivation and starvation stress. Proc. Indian Acad. Sci, 88B: 363-365.

Ayoub S.M.H. and Yankov L.K., 1986. The molluscicidal factor of tannin-bearing plants. Int. J. Crude Drug. Res, 24: 16-18.

Cwiklinski K., O’Neill S.M., Donnelly S. and Dalton J.P., 2016, A prospective view of animal and human Fasciolosis. Parasite Immunology, 38:558-568.

Hemalatha S., Laloo D., Prasad S.K. and Krishnamurthy S., 2013. Gastroprotective activity of ethanolic root extract of Potentilla fulgens Wall. Ex Hook. Journal of Ethnopharmacology, 146: 505-514.

Jaiswal P. Kumar P., Singh V.K. and Singh D.K., 2010. Enzyme inhibition by molluscicidal components of Myristica fragrans Houtt. in the nervous tissue of snail Lymnaea acuminata. Enzyme Research, 2010:1-6.

Jaitak V., Kaul V.K., Himlata N., Kumar B., Singh J., Dhar. and Sharma O.P., 2010. New hopane triterpenes and antioxidant constituents from Potentilla fulgens. Net Prod. Commun, 5: 15611566.

Kumar P, Singh V.K. and Singh D.K., 2012. Enzyme activity in the nervous tissue of Lymnaea acuminata fed to different bait formulations. American Journal of Chemistry, 2(2): 89-93.

Kumar P. and Singh D.K., 2006. Molluscicidal activity of Ferula asafoetida, Syzygium aromaticum and Carum carvi and their active components against the snail Lymnaea acuminata. Chemosphere, 63: 1568-1574.

Kumar P. and Singh V.K. and Singh D.K., 2009. Kinetics of enzyme inhibition by active molluscicidal against ferulic acid, umbelliferone, eugenol and limonene in the nervous tissue of snail Lymnaea acuminata. Phytotherapy Research, 23: 172-177.

Kumar P., Singh V.K. and Singh D.K., 2011. Bait formulation of molluscicides with attractants amino acids against the snail Indoplanorbis exustus. Pharmacologyonline, 3: 536-542.

Kumar P., Singh V.K. and Singh D.K., 2012. Attractant food pellets containing molluscicides against the fresh water snail Indoplanorbis exustus. Global Vet, 8: 105-110.

Kumar P., Sunita K. and Singh D.K., 2018. Molluscicidal activity of different organic root extract of Potentilla fulgens against liver fluke vector snail Indoplanorbis exustus. Asian J. Anim. Sci, 12: 30-35.

Kumar P., Sunita K., Singh V.K. and Singh D.K., 2014. Fecundity, hatchability and survival of Indoplanorbis exustus fed to bait containing attractant and molluscicides. N.Y. Sci. J, 7: 1-5.

Kumar P., V.K. Singh and D.K. Singh, 2013. Reproduction of Lymnaea acuminata fed to bait containing binary combination of amino acid with molluscicide. J Biology and Earth Sciences, 3(1): B65-B71.

Marston A. and Hostettmann K., 1985. Plant molluscicides. Phytochemistry, 24: 639-652.

Mas-Coma S., Bargues M.D. and Valero M.A.., 2014. Diagnosis of human fascioliasis by stool and blood techniques: update for the present global scenario. Parasitology, 141(1): 1918-1946.

Mas-Coma S., Bargues M.D. and Valero M.A., 2018. Human fascioliasis infection sources, their diversity, incidence factors, analytical methods and prevention measures. Parasitology, 145(13 Special Issue):1665-1699.

Mello-Silva C.C., Vilar M.M., Bezerra J.C.B., de Vasconcellos M.C., Pinheiro J., Lerdes. and Rodrigues M., 2007. Reproductive activity alterations on the Biomphalaria glabrata exposed to Euhporbia splendens var. hislopi latex. Mem. Inst. Oswaldo Cruz, 102 (6): 671674.

Parr S.L. and Gray J.S., 2000. A strategic dosing scheme for the control of fasciolosis in cattle and sheep in Ireland. Vet. Parasitol, 88(3-4): 187-197. 
Rosangkima G. and Prasad S.B., 2004. Antitumour activity of some plants from Meghalaya and Mizoram against Murine ascites Dalton's lymphoma. Indian J. Exp. Biol., 42: 981-8.

Roy B., Swargiary A., Syiem D. and Tandon V., 2010. Potentilla fulgens (Family Rosaceae), a medicinal plant of North-East India: A natural anthelmintic. J. Parasit Dis, 34: 83-88.

Singh A. and Singh D.K., 2004. Effect of herbal molluscicides and their combinations on the reproduction of the snail Lymnaea acuminata. Arch. Environ. Contam. Toxicol, 46: 470-477.

Singh A., Singh D.K., Mishra T.N. and Agarwal R.A., 1996. Molluscicide of Plant origin. Bio. Agric. and Horti, 13: 205-252.

Singh N., Kumar P. and Singh D.K., 2012. Variant abiotic factors and the infection of Fasciola gigantica larval stages in vector snail
Indoplanorbis exustus. J. Bio. Earth. Sci, 2: B110-B117.

Singh O. and Agarwal R.A., 1981. Toxicity of certain pesticides to two economic species of snails in northern India. Journal of Economic Entomology, 74: 568-571.

Sokal R.R and Rohlf F.J., 1973. Introduction of biostatistics, W. H. Freeman, San Francisco, 185-207.

Timmermans L.P.M., 1968. Studies on shell formation in mollusks. Netherland Journal of Zoology. 4(19): 413-523.

Tripathi S.M, Singh V.K., Singh S. and. Singh D.K, 2004. Enzyme inhibition by molluscicidal agent Punica granatum Linn. Bark and Canna indica Linn. Root. Phytotherapy Research. 18(7): 501506. 